\title{
Työntekijä tiedon kuluttajasta sen tuottajaksi
}

\author{
Kasvi, Jyrki J. \& Vartiai- \\ nen, Matti (toim.) \\ 2000. Organisaation \\ muisti. Tieto työn tu- \\ kena. Helsinki: \\ EDITA
}

\section{Jyrki Kasvin ja Matti}

Vartiaisen kirjan lähtökohtana on olettamus, että työn oppiminen tapahtuu parhaiten työn ääressä, mutta työsuorituksen tueksi tarvitaan tietotukea. Tätä tukea voi saada omaan muistiin varastoituneesta kokemuksesta, tekemisen ja ymmärtämisen apuna ja tunnetukena sosiaaliselta ympäristöltä, tarkoituksenmukaisesti muotoillulta fyysiseltä ympäristöltä ja tehokkaalta informaatioympäristöltä. Työn tietointensiivisyyden lisääntyessä ja tuotteiden elinkaaren lyhentyessä perinteinen työnopastus, muistilaput, laatukansiot, ohjekirjat tai työpaikkakoulutus eivät pysty reagoimaan tarpeeksi herkästi ja nopeasti lisääntyneeseen tekijän tiedon tarpeeseen. Organisaatiossa on apua etsittävä modernin informaatioteknologian tukemasta informaatioympäristöstä.

\section{Näkökulman vaihtaminen} työnopastuksesta ja perehdyttämiskoulutuksesta tietotukeen on sopusoinnussa sen kanssa, että näkökulma yleensäkin on vaihtunut opettamisesta oppimiseen. Työssä tarpeellisen tiedon tarpeen määrittelee työntekijä itse samoin kuin sen, milloin hän mitäkin tietoa tarvitsee. Tietotuen järjestelmästä muodostuu näin työntekijälle eräänlainen apu- muisti. Työntekijä jalostuu tiedon kuluttajasta tiedon tuottajaksi vuorovaikutteisissa tietotukijärjestelmissä, hän kun voi kirjoittaa järjestelmään omia kokemuksiaan ja havaintojaan muiden jaettavaksi. Yrityksen tasolla kartutetaan organisaatiopääomaa tai, niin kuin tekijät prosessia kutsuvat, organisaation muistia. Kirjoittajat määrittelevät organisaation muistin tietotuen informaatio(tieto)kannaksi. Tietotuen he määrittelevät työ-, menetelmä- ja tuotetiedon hallinnaksi, välittämiseksi, ja kumuloimiseksi, jota toimintaa tietotekniikan sovelluksin voidaan tuntuvasti tehostaa.

\section{Sulautetussa tietotuessa} tuki on upotettu itse työprosessiin jonkin toisen järjestelmän osana niin, että työntekijä ei aina edes huomaa tukeutuvansa siihen. Erillinen tietotukijärjestelmä on kysymyksessä esimerkiksi silloin, kun tietokone ei ole ensisijainen työväline. Ohjelma voi opastaa esimerkiksi monimutkaisen kokoonpanon työvaiheissa. Linkitetty järjestelmä on yhteydessä varsinaiseen sovellukseen. Tyypillinen on tekstikäsittelyohjelman help ohjeohjelma, johon tekstikäsittelyä suorittaessaan voi turvautua. Langattomat verkkoyhteydet, kehittyneet ja monipuoliset käyttöliittymät (esimerkiksi puheella tai silmänliikkeellä ohjattavat) ja puettavat tietokoneet silloin, kun tekijän käsien on oltava vapaana ja tietokoneen on seurattava mukana kaikissa työvaiheissa hankalissakin paikoissa, mahdollistavat yhä monipuolisemman, nopeamman ja tehokkaamman tietotuen käyttöön oton. Ja kysymys ei ole vain tietoteknisistä utopioista. Kirjassa esitellään monin esimerkein valaistusta käytännön kehittämistyöstä, jota kirjoittajat Teknillisen korkeakoulun Työpsykologian ja johtamisen laboratoriossa ovat yli vuosikymmenen ajan tehneet. Tietotuen käyttöönotossa ja soveltamisessa on monia vaikeuksia, mutta tekijät esittelevät myös keinoja näiden vaikeuksien vähentämiseksi. Kokoava johtopäätös on, että tämäkin muutosprosessi vaatii aktiivisen ja visionäärisen muutosagentin ja hänelle delegoidun vastuun, jotta tietotuki saavuttaa sille asetetut tavoitteet. Tekijät varoittavat uuden teknologian käyttöönotosta pelkästään sen imagoarvon vuoksi.

\section{Kirjan kieli on viileätä,} jopa kuivaa, ja se varoo hehkuttamasta liikaa uuden tekniikan puolesta. Paikoin tekijät kuitenkin luiskahtavat ylioptimistisiin odotuksiin, esimerkiksi olettaessaan tietotekniikan olevan uusi ase kaiken hiljaisen tiedon eksplikointiin ja käyttöönottoon koko yrityksessä. Tiedon hierarkiassa viisaus määritellään kovin praktisesti uuden tiedon tuottamiseksi, ja lainausmerkit termin "viisausteknologia" ympärillä eivät paljon pelasta. Heikoimmillaan ja kapeimmillaan teksti on puhuessaan tietotuen psykologisesta perustasta ja oppimisesta. Lähteet ovat vanhoja, ja käsitteet jäävät päälle liimatuiksi 
nimilapuiksi (esim. konstruktivismi.). Keskeisiksi mallintaviksi näkökulmiksi on valittu eklektisesti satunnaisia lähteitä (toiminnan säätelyn "teoria”, toimintojen helpottamisen malli). Esimerkiksi European Science Foundationin projekti Learning in Humans and Machines on kuudessa loppuraportissaan tuottanut erinomaista tietoa tietotuen kehittämisenkin näkökulmasta. Yliopistojen laitosten ja laboratorioiden työssä on yleensäkin ongelmana kapeaalaisuus. Kehittämistiimit tarvitsisivat moni- ja poikkitieteistä asiantuntijuutta.

\section{Kirjan käyttämät käsitteet} avautuvat yleensä hyvin lukijalle. Paljon palstatilaa saaneen redundanssin käsitteen tarpeellisuudesta olen kuitenkin kirjoittajien kanssa eri mieltä. Sillä on vakiintunut käyttönsä tekniikassa (esimerkiksi redundanssi- 1. varajärjestelmä), kielitieteessä ja psykologiassa, ja käyttö poikkeaa täysin kir- jassa käytetystä redundanssin käsitteestä. Epäselväksi lisäksi jää, mitä kirjoittajat tarkoittavat käsitteellä. Sitä on käytetty ainakin neljässä merkityksessä: joustoa, lisäkapasiteettia, monitaitoisuutta tai -toimisuutta sekä yleensä toimivuutta kuvaamaan. Käsite sekoittaa artikkelien sisältämän selkeän "juonen".

\section{Kirja esittää myös} terävää kritiikkiä tietotukijärjestelmien käyttöä kohtaan. Erityisesti Electronic Performance Support System -järjestelmässä (EPSS) nähdään työntekijän kontrolloimisen, työn osittamisen ja köyhtymisen, luovuuden tappamisen ja yleensäkin osaamisen katoamisen vaara. Järjestelmä vaatii usein raskaita teknisiä ratkaisuja, joiden käytön opettelu kuormittaa lisää työntekijöitä tai käyttö laskee tuottavuutta. Uhka pakkotahtisen työn lisäämisen on olemassa. Käyttäjän tarpeisiin tapahtuva räätälöinti on usein puutteel- lista ja päivittäminen hidasta. Tietotukijärjestelmä jää usein integroimatta yrityksen muihin tiedonhallintajärjestelmiin ja saattaa aiheuttaa yhteensopivuusongelmia.

\section{Kirjan tekstiä tukee}

runsas selventävä kuvitus, uutta asiaa edeltävät esijäsentäjät ja erinomainen hakemisto. Tekstin lomaan on ujutettu runsaasti (usein varottavasta näkökulmasta) esimerkkejä ja tekijöiden tutkimusekskursiota. Tarpeeksi yksityiskohtaista tietoa kirja ei anna siihen, että lukija voisi ryhtyä kilpailemaan kirjoittajien kanssa tietotukimarkkinoilla, mutta hyvän ja tiiviin taustan kehittämistyölle ja sen ymmärtämiselle teos tarjoaa. Mielenkiintoisia kytkentöjä se tarjoaa myös äly- ja organisaatiopääoman sekä hiljaisen tiedon ja kognitiivisten taitojen tutkijalle.

Reijo Raivola 